\title{
NUTRIENT DIGESTIBILITY AND GROWTH RATE OF BULL CALVES FED RICE STRAW TREATED WITH WOOD ASH EXTRACT
}

\author{
M. M. Rahman ${ }^{1 *}$, M. A. Akbar ${ }^{1}$, K. M. S. Islam ${ }^{1}$, A. B. M. Khaleduzzaman ${ }^{1}$ and \\ A. B. M. R. Bostami ${ }^{2}$
}

\begin{abstract}
An experiment was conducted for a period of 60 days with twelve bull calves with an average live weight of $77.78 \pm 10.96 \mathrm{~kg}$ to determine the effect of treatment of rice straw with Wood Ash Extract (WAE) on feed intake, nutritive value, growth rate and economic benefits. The experimental animals were divided into three groups $A$, $B$ and $C$ having four animals in each. They were supplied randomly with three rations following randomized complete block design. All rations were made isonitrogenous by using urea as a source of nitrogen. Animals of group A were fed untreated rice straw, whereas, group $B$ and $C$ were fed urea-treated and WAE treated rice straw, respectively. The chemical analysis showed that treatment of rice straw with WAE increased ash content of straw from $13.93 \%$ to $16.45 \%$ and decreased the NDF content from $67.39 \%$ to $63.00 \%$. The daily DM intake per 100 $\mathrm{kg}$ live weight of diet $B$ was significantly $(P<0.01)$ higher than that of diet $A$ and $C$. The daily CP intake per $100 \mathrm{~kg}$ body weight of diet B (553.3g) was significantly $(P<0.05)$ higher than that of diet $A(449.5 \mathrm{~g})$. Similarly, the organic matter $(\mathrm{OM})$ intake in bull calves fed diet $B$ was significantly $(P<0.05)$ higher than those fed diet $A$ and $C$. The average daily live weight gain with diet $B$ and $C$ was significantly $(P<0.01)$ higher than diet $A$. The animals fed diet $B$ and $C$ were more efficient in converting feed into live weight than animals fed diet $A$. Treating rice straw with wood ash extract improved the nutritive value, it significantly $(P<0.01)$ increased the apparent digestibility of DM, OM, CP, ADF and NDF. It also increased the DCP, DOM, DNDF and DADF contents of rice straw compared with untreated straw. Although the total feed cost of untreated group is lower than those of WAE and urea-treated groups, the feed cost per $\mathrm{kg}$ live weight gain as well as the feed cost per $\mathrm{kg}$ meat production of WAE and urea-treated groups were significantly $(P<0.01)$ lower than that of untreated rice straw. It may be concluded that nutrient composition and digestibility of rice straw and live weight gain of animals can be improved by treating rice straw with wood ash extract.
\end{abstract}

Key words: Straw, Bull calves, Wood ash extract, Nutrient digestibility, Growth rate

\section{Introduction}

Under-nutrition due to inadequate and fluctuating feed supply is a major constraint to the improvement of productivity and health of livestock. The farmers do not grow fodder for

\footnotetext{
* Corresponding author: Md. Mostafizar Rahman. E-mail: md_rahman60@yahoo.com

1 Department of Animal Nutrition, Bangladesh Agricultural University, Mymensingh-2202, Bangladesh

${ }^{2}$ Scientific Officer, Bangladesh Livestock Research Institute, Savar, Dhaka-1341, Bangladesh
}

(Received: September 10, 2009) 
feeding livestock as lands are used intensively for crop production. The chief source of roughage for ruminant livestock in the country is rice straw.

Rice straw alone contributes 87 percent of total available roughages and 90 percent of dry matter intake of ruminants (Tareque, 1991). It contributes to the major portion of fibrous part of diet of ruminants. Straws and stovers are staple livestock feed of SouthEast Asia, and interest in their use as livestock feed is increasing day by day as the price of better quality feeds goes up (Jackson, 1977). However, straw has low nitrogen and high cellulose and hemicellulose which are mostly indigestible. Furthermore, the poor digestibility of rice straw is due to the presence of higher amount of lignin and silica (Sing and Oasting, 1991). Due to poor digestibility intake of rice straw by animal is also low. Poor digestibility and low intake of straw by ruminants have limited its use as feed (Males, 1987). The possible alternative for better utilization of straw is to improve its digestibility through treatment with appropriate chemical or biological agents or by physical means so that its lignocellulose bond is broken or at least loosened to free major portion of cellulose to be digested by the animals. Among them chemical treatment received most attention by the scientists, particularly treatment with urea or urea and molasses (Akbar, 1992; Akbar and Tareque, 1990 and Saadullah et al., 1982). Although urea treatment increases the digestibility of straw but it was not well accepted by the farmers due to the fact that the method is tedious and time consuming and dangerous particularly for rural farmer (Akbar, 1992).

Alkali treatment of straw are effective in loosening the lignocellulose complex and increasing digestibility better than urea treatment (Schiere and Ibrahim, 1989 and Chenost and Kayouli, 1997) but the method did not get popularity because of its corrosive nature. As an alkali wood ash extract may be an effective alternative of straw treatment to improve its digestibility in the rumen of animals (Kimambo et al., 2003). Wood ash is easily available in rural area eventually without any cost and due to its alkaline properties, may be used for treatment of rice straw. But no research work has yet been conducted in Bangladesh to monitor its effectiveness for straw treatment. Therefore, the present research work was undertaken to investigate the effect of feeding rice straw treated with wood ash extract on intake, digestibility and growth rate of bull calves.

\section{Materials and Methods}

An experiment was conducted to investigate the effect of feeding rice straw treated with wood ash extract on nutrient digestibility and growth rate of indigenous bull calves. Twelve growing bull calves with an average live weight of $77.78 \pm 10.96 \mathrm{~kg}$ were divided into three groups (A, B and $C$ ) having four in each and arranged in randomized block design (RBD) according to live weight. The animals of diet $A$ received untreated straw while diet $B$ received $4 \%$ urea ensiled straw and diet $C$ received wood ash extract (WAE) treated straw. Animals of each group were given straw ad libitum, $1 \mathrm{~kg}$ green grass, and $1 \mathrm{~kg}$ concentrate mixture per $77.78 \mathrm{~kg}$ of live weight. All the diets were isonitrogenous. Formulation of diets and chemical composition are shown in Table 1 . The 
concentrates (wheat bran, rice polish, mustard oil cake, molasses, and common salt), wood ash and commercial fertilizer grade urea were purchased from local market. Preparation of wood ash extract (WAE) treated rice straw is shown in Fig. 1.

Table 1. Formulation and chemical composition of different diets

\begin{tabular}{|c|c|c|c|}
\hline \multirow{2}{*}{ Parameters } & \multicolumn{3}{|c|}{ Experimental diets ${ }^{\#}$} \\
\hline & A & B & C \\
\hline \multicolumn{4}{|l|}{ Ingredients } \\
\hline Straw (kg) & 2.0 & 4.0 & 2.0 \\
\hline Green grass (kg) & 1 & 1 & 1 \\
\hline Concentrate mixture $(\mathrm{kg})^{@}$ & 1 & 1 & 1 \\
\hline \multicolumn{4}{|l|}{ Nutrient composition } \\
\hline Crude protein (kg/100 kg DM) & 14.76 & 14.90 & 14.81 \\
\hline Metabolizable energy (MJ/kg DM)* & 23.55 & 27.26 & 23.55 \\
\hline
\end{tabular}

${ }^{\#}$ Diet $\mathrm{A}=$ Untreated rice straw, $\mathrm{B}=$ Urea treated rice straw, $\mathrm{C}=$ WAE treated rice straw

* Estimated from NRC (1984)

$@$ Concentrate mixture $=(40 \%$ of wheat bran, $35 \%$ of rice polish, $23.5 \%$ of mustard oil cake and $1.5 \%$ common salt)

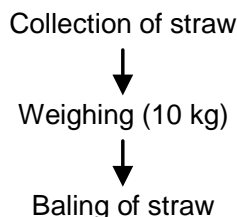

Baling of straw

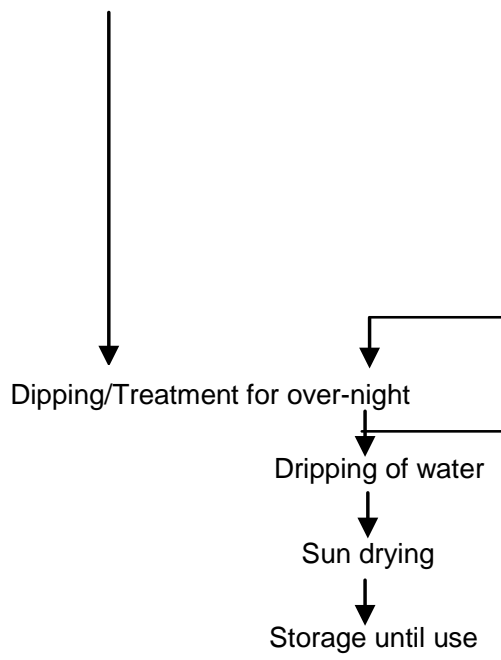

Collection of wood ash

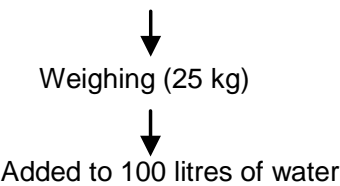

Added to 100 litres of water

Extraction for 48 hours

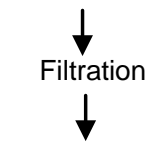

Wood ash extract

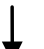

Fig. 1. Preparation of wood ash extract and its use in treatment of rice straw 
All ingredients for concentrate mixture were taken proportionately, mixed uniformly, and supplied to individual animal based on live weight. Feeds were supplied to the animals twice daily at $8.00 \mathrm{AM}$ and at 4.00 PM. Untreated and treated rice straw along with green grass was supplied after concentrate mixture. Animals were housed hygienically in a well-ventilated face-out stanchion barn and all animals were marked with tag number. Feed intake was recorded by subtracting left over from the supplied feed. Live weight gain was measured by subtracting initial live weight from final live weight. The daily weight gain was calculated by dividing the total weight gain by number of days in the experiment. A conventional digestion trial was conducted for a period of 7 days to find out the digestibility of feed nutrients. The samples of straw, green grass, faces and concentrate mixture were sundried, grinded and kept in polythene bag for chemical analysis.

\section{Chemical analysis}

Samples of feed, feed refusals, and faeces were analyzed for dry matter (DM), ash, crude protein $(C P)$, ether extract $(E E)$ and organic matter (OM) according to the standard procedures of AOAC (1990). The neutral detergent fibre (NDF) and acid detergent fibre (ADF) were analyzed according to Van Soest et al. (1991) method.

\section{Data analysis}

The data were analyzed using the 'MSTAT-C' computer program to compute analysis of variance (ANOVA) for Randomized Block Design (RBD). The difference among treatment means was determined by Duncan's Multiple Range Test (Steel and Torrie, 1980).

\section{Results}

\section{Chemical composition of dietary ingredients}

The average nutrient composition of untreated, urea treated and WAE treated rice straw as well as other ingredients used in this experiment is presented in Table 2. The WAE treated rice straw contained slightly lower NDF and slightly higher ash than untreated and urea treated rice straw.

Table 2. Chemical composition of different experimental feed ingredients

\begin{tabular}{|l|c|c|c|c|c|c|c|}
\hline \multirow{2}{*}{\multicolumn{1}{|c|}{ Ingredients }} & \multirow{2}{*}{$\begin{array}{c}\text { DM } \\
\text { (g/100g) }\end{array}$} & \multicolumn{5}{c|}{ Chemical composition (g/100g DM) } \\
\cline { 3 - 8 } & & OM & CP & EE & NDF & ADF & ASH \\
\hline Untreated rice straw & 71.71 & 86.07 & 3.20 & 0.92 & 67.39 & 45.21 & 13.93 \\
Urea-treated rice straw (4\% urea) & 55.65 & 85.53 & 13.04 & 1.13 & 63.67 & 45.46 & 14.47 \\
WAE treated rice straw & 70.67 & 83.55 & 3.40 & 1.47 & 63.00 & 45.34 & 16.45 \\
Mixed grass & 17.49 & 91.15 & 9.45 & 1.28 & 65.58 & 36.21 & 8.85 \\
*Concentrate mixture & 86.58 & 91.80 & 17.58 & 7.04 & 36.94 & 14.06 & 8.86 \\
\hline
\end{tabular}

* Concentrate mixture contained $40 \%$ wheat bran, $35 \%$ rice polish, $25 \%$ mustard oil cake and $1.5 \%$ common salt 


\section{Feed intake}

The average DM, OM and CP intake of bull calves fed diet $A, B$ and $C$ are presented in Table 3. Total DM intake and DM intake per $100 \mathrm{~kg}$ body weight of diet $B$ were significantly $(P<0.01)$ higher than that of diet $A$ and $C$. Organic matter intake in bull calves fed diet $B$ was significantly $(P<0.05)$ higher than those of fed diet $A$ and $C$. Crude protein intake $(\mathrm{kg} / 100 \mathrm{~kg} \mathrm{LW})$ of diet $B$ was significantly $(P<0.05)$ higher than $\operatorname{diet} A$ and tended to be higher from diet C (Table 3).

Table 3. Effect of different diets on intake of nutrients and growth performances of bull calves

\begin{tabular}{|l|c|c|c|c|c|}
\hline \multirow{2}{*}{ Parameters } & \multicolumn{3}{c|}{ Experimental diets $^{\#}$} & \multirow{2}{*}{ SEM } & $\begin{array}{c}\text { Level of } \\
\text { sig. }\end{array}$ \\
\cline { 2 - 5 } & A & B & C & & $*$ \\
Intake & & & & & \\
Total DM intake (kg) & $158.2^{\mathrm{b}}$ & $204.1^{\mathrm{a}}$ & $164.7^{\mathrm{b}}$ & 8.829 & $*$ \\
DM intake (kg/h/d) & $2.71^{\mathrm{b}}$ & $3.70^{\mathrm{a}}$ & $2.88^{\mathrm{b}}$ & 0.156 & $*$ \\
DM intake (kg/100 kg LW) & $2.99^{\mathrm{b}}$ & $3.77^{\mathrm{a}}$ & $3.00^{\mathrm{b}}$ & 0.135 & $*$ \\
OM intake (kg/h/d) & $2.43^{\mathrm{b}}$ & $3.23^{\mathrm{a}}$ & $2.59^{\mathrm{b}}$ & 0.181 & $*$ \\
CP intake (g/100 kg LW) & $449.5^{\mathrm{b}}$ & $553.3^{\mathrm{a}}$ & $475.5^{\mathrm{ab}}$ & 22.99 & $*$ \\
Live weight & & & & & \\
Initial live weight (kg/h) & 77.80 & 77.85 & 77.68 & 1.492 & NS \\
Final live weight (kg) & $91.88^{\mathrm{b}}$ & $103.48^{\mathrm{a}}$ & $101.08^{\mathrm{a}}$ & 2.591 & $*$ \\
Total live weight gain (kg) & $14.08^{\mathrm{b}}$ & $25.63^{\mathrm{a}}$ & $23.40^{\mathrm{a}}$ & 1.473 & $*$ \\
Live weight gain (g/d) & $234.8^{\mathrm{b}}$ & $427.0^{\mathrm{a}}$ & $390.0^{\mathrm{a}}$ & 24.50 & $*$ \\
FCR (kg DMl/kg LWG) & $13.55^{\mathrm{b}}$ & $7.97^{\mathrm{a}}$ & $7.34^{\mathrm{a}}$ & 1.793 & $* *$ \\
\hline
\end{tabular}

${ }^{\#} A=$ Untreated rice straw, $B=$ Urea-treated rice straw (4\% urea), $C=$ WAE treated rice straw

SEM $=$ Standard error of means

NS = Non-significant; ${ }^{*}$ Significant $(P<0.01),{ }^{*}$ Significant $(P<0.05)$

${ }^{\mathrm{ab}}$ Mean values with different superscripts differ significantly

\section{Live weight gain}

The live weight gain and feed conversion ratio of bull calves fed diet $A, B$ and $C$ are presented in Table 3. The bull calves fed diet $B$ and $C$ gained significantly $(P<0.01)$ higher live weight those fed diet $A$ but the difference between $\operatorname{diet} B$ and $C$ was not statistically significant $(P>0.05)$. Similarly, the daily live weight gain in bull calves of diet $B$ and $C$ were significantly $(P<0.01)$ higher than that of diet $A$.

\section{Feed conversion ratio}

In the present experiment it was seen that the bull calves fed diet B and C were more efficient in converting feed into body weight gain than those fed diet A (Table 3).

\section{Apparent digestibility of nutrients}

The apparent digestibility of nutrients of different diets are shown in Table 4. The digestibility for DM and OM of diet $B$ (urea treated) were significantly $(P<0.01)$ higher than those of diet A (untreated) and diet C (WAE treated). The DM and OM digestibility of diet $C$ was significantly $(P<0.01)$ higher than that of diet $A$. The NDF and ADF 
Bang. J. Anim. Sci. 2009, 38(1\&2)

digestibility of diet $A, B$ and $C$ were varied significantly $(P<0.01)$ where the highest value was found in diet $B$ followed by diet $C$ and $A$.

Table 4. Apparent digestibility and nutritive values of different diets

\begin{tabular}{|c|c|c|c|c|c|}
\hline \multirow{2}{*}{ Parameters } & \multicolumn{3}{|c|}{ Experimental diets $^{\#}$} & \multirow{2}{*}{ SEM } & \multirow{2}{*}{$\begin{array}{l}\text { Level of } \\
\text { sig. }\end{array}$} \\
\hline & A & B & C & & \\
\hline \multicolumn{6}{|l|}{ Nutrient digestibility (g/100 g) } \\
\hline Dry matter & $46.91^{c}$ & $58.51^{\mathrm{a}}$ & $52.75^{\mathrm{b}}$ & 0.885 & ** \\
\hline Organic matter & $50.74^{c}$ & $62.75^{\mathrm{a}}$ & $57.97^{b}$ & 1.119 & ** \\
\hline Crude protein & 61.11 & 65.35 & 66.13 & 1.281 & NS \\
\hline Neutral detergent fibre (NDF) & $49.37^{\mathrm{C}}$ & $64.24^{\mathrm{a}}$ & $56.24^{b}$ & 1.169 & ** \\
\hline Acid detergent fibre (ADF) & $47.24^{c}$ & $63.51^{\mathrm{a}}$ & $56.42^{b}$ & 1.443 & ** \\
\hline \multicolumn{6}{|l|}{ Nutritive values (g/100 g DM) } \\
\hline Digestible organic matter (DOM) & $43.67^{\mathrm{c}}$ & $53.67^{\mathrm{a}}$ & $50.22^{b}$ & 0.960 & ** \\
\hline Digestible crude protein (DCP) & $7.89^{\mathrm{b}}$ & $8.52^{\mathrm{a}}$ & $8.59^{\mathrm{a}}$ & 0.163 & * \\
\hline Digestible NDF (DNDF) & $34.74^{\mathrm{c}}$ & $43.73^{\mathrm{a}}$ & $39.92^{b}$ & 0.814 & ** \\
\hline Digestible ADF (DADF) & $21.36^{\mathrm{c}}$ & $28.87^{\mathrm{a}}$ & $25.58^{\mathrm{b}}$ & 0.653 & $\star \star *$ \\
\hline $\mathrm{ME}(\mathrm{MJ} / \mathrm{kg} \mathrm{DM})$ & $6.99^{c}$ & $8.59^{a}$ & $8.04^{b}$ & 0.154 & $\star \star *$ \\
\hline
\end{tabular}

${ }^{\#} \mathrm{~A}=$ Untreated rice straw, $\mathrm{B}=$ Urea-treated rice straw (4\% urea), $\mathrm{C}=$ WAE treated rice straw SEM $=$ Standard error of means

NS = Non-significant; **Significant $(P<0.01)$; * Significant $(P<0.05)$

${ }^{a b c}$ Mean values with different superscripts differ significantly

\section{Nutritive value of different diets}

The nutritive values of different diets are shown in Table 4. The DOM, DCP, DNDF, DADF and ME values were significantly varied $(P<0.01)$ among the diets where all the values in diet $B$ were found highest followed by diet $C$ and $A$ except in the case of DCP. The DCP contents of the $B$ and $C$ were significantly $(P<0.05)$ higher than diet $A$.

The relationship between NDF digestibility of different diets and live weight gain of bull calves are shown in Fig. 2. It can be seen from the figure that there is a positive relationship $\left(R^{2}=0.858\right)$ between the digestibility of NDF and live weight gain of bull calves.

\section{Economics of meat production on different diets}

The cost of feed for meat production of growing bull calves fed different diets is shown in Table 5. The feed cost of rearing animals was calculated based on the market price (2008) of ingredients used in the present experiment. The estimated cost of green grass and collection cost of wood ash per kg was about Tk. 1.00 and 0.50 , respectively.

Total feed cost was significantly different $(P<0.01)$ among the diets having the highest in diet $B$ followed by of diet $C$ and $A$. Moreover, daily cost of roughage of diet B was significantly $(P<0.01)$ higher than that of diet $C$. The total feed cost per $\mathrm{kg}$ live weight gain of diet $A$ was significantly $(P<0.01)$ higher than that diet $B$ and $C$, however, there was no difference between diets $B$ and $C$. 


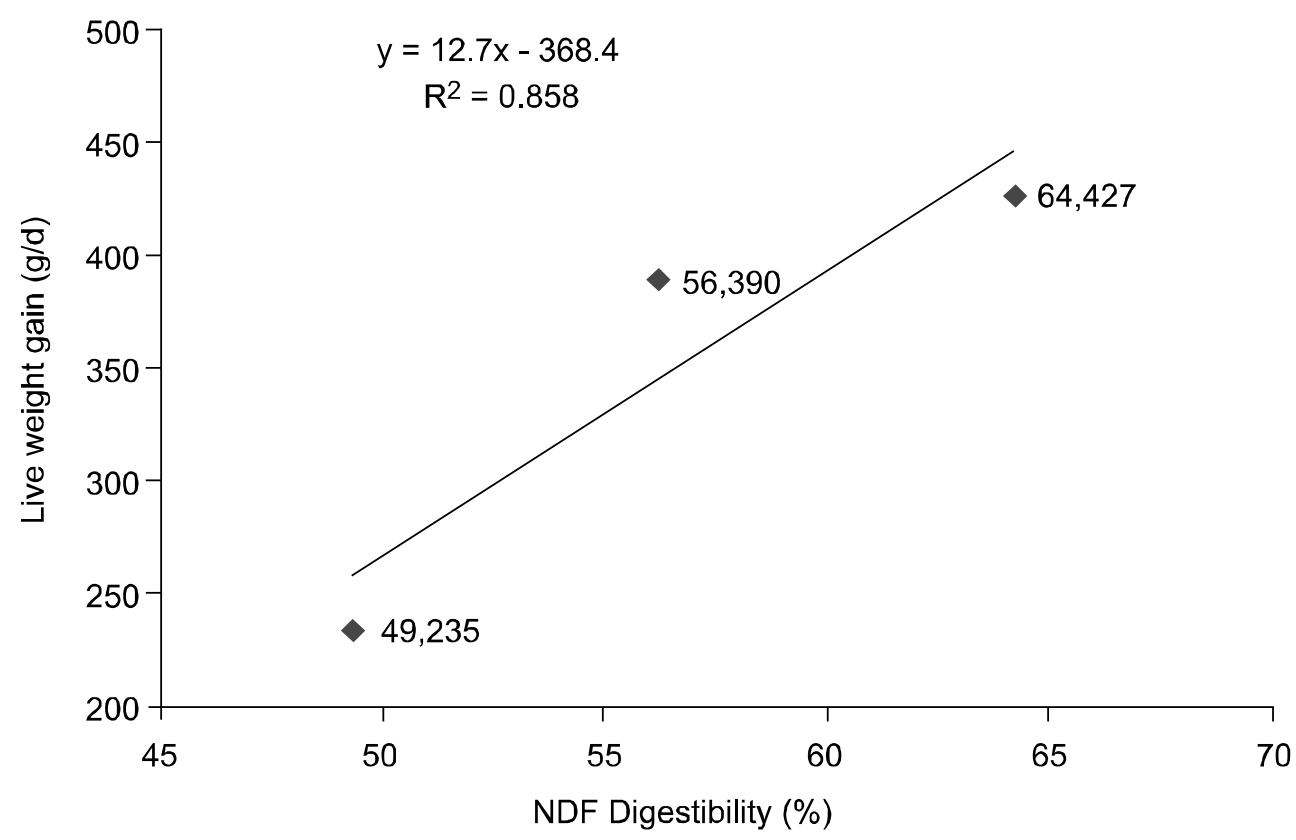

Fig. 2. Correlation between NDF digestibility and live weight gain of bull calves fed different diets

Table 5. Cost of feed for meat production of bull calves fed different diets

\begin{tabular}{|c|c|c|c|c|c|}
\hline \multirow{2}{*}{ Parameters } & \multicolumn{3}{|c|}{ Experimental diets } & \multirow{2}{*}{ SEM } & \multirow{2}{*}{$\begin{array}{l}\text { Level of } \\
\text { sig. }\end{array}$} \\
\hline & A & B & C & & \\
\hline Cost of roughage diet (Tk/d) & $7.70^{\mathrm{C}}$ & $13.45^{\mathrm{a}}$ & $10.65^{\mathrm{b}}$ & 0.54 & $\star \star$ \\
\hline Cost of concentrate diet (Tk/d) & 19.70 & 19.79 & 19.80 & 0.71 & NS \\
\hline Total feed cost (Tk) & $1649^{b}$ & $1995^{\mathrm{a}}$ & $1827^{\mathrm{a}}$ & 50.66 & ** \\
\hline Total feed cost/ kg LWG (Tk) & $147.3^{\mathrm{a}}$ & $77.75^{\mathrm{b}}$ & $78.75^{b}$ & 5.62 & ** \\
\hline $\begin{array}{l}\text { Estimated carcass yield }(\mathrm{kg}) @ 45 \% \\
\text { dressing percentage }\end{array}$ & $6.34^{\mathrm{b}}$ & $11.53^{\mathrm{a}}$ & $10.53^{\mathrm{a}}$ & 0.33 & ** \\
\hline Total feed cost/kg meat produced (Tk) & $326.8^{\mathrm{a}}$ & $173.0^{\mathrm{b}}$ & $174.8^{\mathrm{b}}$ & 15.46 & $\star \star$ \\
\hline
\end{tabular}

\# $A=$ Untreated rice straw, $B=$ Urea-treated rice straw (4\% urea), $C=$ WAE treated rice straw

$\mathrm{SEM}=$ Standard error of means

NS = Non-significant; ${ }^{*}$ Significant $(P<0.01)$

abc Mean values with different superscripts differ significantly

Estimated carcass yield and cost of meat production of bull calves fed different diets are also shown in Table 5. It is evident from the table that animals fed on diet $A$ had significantly $(P<0.01)$ lower carcass yield than those fed diet $B$ and $C$, respectively. Carcass yield and cost of meat production in dietary groups $B$ and $C$ were almost similar. 
Bang. J. Anim. Sci. 2009, 38(1\&2)

\section{Discussion}

Crude protein content of urea-treated rice straw was $13.04 \%$, which was comparable with the findings of Mohanta (2005) and Mgheni et al. (1993) but was slightly higher $10.84 \%$ than that reported by Kamruzzaman (2005). Wood ash extract treated rice straw contained higher ash than urea-treated and untreated rice straw and a similar result was recorded by Laswai et al. (2007). The higher ash content in WAE treated straw might be due to the presence of minerals in the extract. Slightly decrease in NDF of the treated straw (both urea and WAE) relative to the untreated straw indicates that the ash extract and urea could have similar effect of attacking the cell wall constituents of the treated materials. This observation is in agreement with those of Nolte et al. (1987), Ramirez et al. (1992) and Laswai et al. (2007) who used WAE for treating straw. However, Mgheni et al. (1993) observed increased proportion of NDF content in urea treated rice straw, which could have resulted from leaching of some of the soluble components during treatment.

The DM intake was not significantly $(P>0.05)$ different between untreated and WAE treated rice straw in the present study and the results are in agreement with the findings of Laswai et al. (2007) but contradict with the findings of Nolte et al. (1987) who fed wheat straws treated with ash extract to goats and observed significantly $(P<0.05)$ higher DM intake than those fed untreated straw. The contradictory result in the present findings and that of Nolte et al. (1987) might be due to the species differences (cattle vs. goat) as well as feeds (rice straw vs. wheat straw).

The increased DM intake either in urea or WAE treated straw was attributed to improved nutrient digestibility as indicated from Table 4 . The observed discrepancy on DM intake in the present study could be due to the confounding effects of molasses and/or urea mixtures, a phenomenon similarly observed by Laswai et al. (2007). The urea molasses mixture increases palatability of straw, rumen $\mathrm{NH}_{3}-\mathrm{N}$ concentration and microbial population hence the improved intake of the untreated straw has been reported by Preston and Leng (1987).

Increased $(P<0.01)$ live weight gain of bull calves fed urea or WAE treated straw in the present study are in the agreement with Puri and Gupta (2001) and Saadullah el al. (1982).

Feed conversion ratio of bull calves fed urea treated straw diet (7.97) is slightly lower than the report of Kamruzzaman (2005) who found 8.55 with the similar treatment. The significantly $(P<0.01)$ lower $F C R$ of diet $B$ and $C$ than that of diet $A$ indicates that the treatment of straw with urea as well as with WAE resulted better potentiality of converting feed into live weight gain. Better feed conversion ratio as observed in the 
treatment groups might be due to higher digestibility of diets (Table 3) and also higher live weight gain of animals than those of the animals of untreated group.

The increased digestibility of DM and OM due to treatment of straw either with urea or WAE over untreated straw indicates that both wood ash extract as well as urea loosens lignocellulose complex and consequently some of the celluloses might have freed for microbial digestion. The DM and OM digestibility of the straw treated with WAE observed were slightly higher than those of straw treated with $3 \% \mathrm{NaOH}$ as reported by Suksombat (2004). The present findings also indicate higher digestibility value for NDF and ADF of straw treated with WAE than those of untreated straw and this is in agreement of Nolte et al. (1987). The non- significant effect for crude protein digestibility corresponds with that found by Laswai et al. (2007). However, higher digestibility value for DM, OM, NDF and ADF of urea-treated rice straw than WAE treated rice straw differs with the findings of Laswai et al. (2007) who observed a higher digestibility value of WAE treated straw than urea-treated straw. This might be due to the difference in alkalinity strength ( $\mathrm{pH} 13$ vs. 10) of the WAE solution used for treating straw.

The higher DCP of urea treated rice straw than untreated straw is in agreement with the findings of Kamruzzaman (2005), who found higher DCP value for urea ensiled rice straw. The higher DCP values of the WAE treated straw than untreated straw can be justified in the similar way. The significantly higher DOM, DNDF and DADF of WAE treated and urea treated rice straw than untreated rice straw indicates that these two alkaline substances can improve the nutritive value of rice straw. Lower feed cost per $\mathrm{kg}$ live weight gain for the treated straw might be due to the fact that the treatment of straw resulted in significantly higher digestibility and consequently higher live weight gain compared to untreated one. Again, the lower feed cost per kg meat production in animal groups fed treated rice straw than untreated rice straw may also be due to same reasons of better utilization of treated straw by the animals.

The increased digestibility of rice straw makes the cellulose more available for microbial digestion. The improved digestibility of straw due to WAE treatment resulted in higher live weight gain, better feed conversion ratio and lower feed cost per kg gain than those of the untreated straw feeding to bull calves. So WAE treated straw may be more acceptable by the farmers compared to urea treated straw due to its availability and price as opposed to those of urea which is having high price and less availability.

\section{Literature Cited}

Akbar, M. A. 1992. Methods of urea incorporation in straw and there effects on performance of buffalo heifers. Asian- Aust. J. Anim. Sci. 5(3): 545-548. 
Bang. J. Anim. Sci. 2009, 38(1\&2)

Akbar, M. A. and Tareque, A. M. M. 1990. Proper utilization of byproducts and locally available feedstuffs in buffalo rations in Bangladesh. In: Domestic Buffalo Production in Asia. Published by the International Atomic Energy Agency, Viena (Austria). pp. 63-74.

AOAC. 1990. Official methods of analysis. $15^{\text {th }}$ Ed. Association of Official Analytical Chemists, Inc., Arlington, Virginia, USA.

Chenost, M. and Kayouli, C. 1997. Roughage utilization in warm climates. FAO animal production and health paper. 135. Rome.

Jackson, M. G. 1977. Rice straw as livestock feed. World Anim. Rev. 28: 38-43.

Kamruzzaman, M. 2005. Effect of feeding urea supplemented and urea ensiled with or without soybean meal on growth and carcass characteristics on indigenous growing bull calves. MS Thesis, Department of Animal Nutrition, Bangladesh Agricultural University, Mymensingh, Bangladesh.

Kimambo, A. E., Aboud, A. A., Laswai, G. H., Nkanwa, P. Anthony, D. and Mtamakaya, J. D. 2003. Investigations on quantify and physical- chemical quality of wood ash in improving the feeding values of poor qualify roughage feeds for ruminants. Tropical and subtropical agroecosystems (Special Volume), 3(1-3): 53.

Laswai, G. H., Kimambo, A. E., Mtamakaya, J. D., Aboud, A. A. and Mtakwa, T. 2007. Dry matter intake, in vivo nutrient digestibility and concentration of minerals in the blood and urine of steers fed rice straw treated with wood ash extract. Anim. Feed Sci. and Tech. 137(1-2): 25-34.

Males, J. R. 1987. Optimizing the utilization of cereal crop residues for beef cattle. J. Anim. Sci. $65: 1124-1130$.

Mgheni, D. M., Kimambo, A. E., SundstøI, F. and Madsen, J. 1993. Influence of urea treatment or supplementation on degradation, intake and growth performance of goats fed rice straw diets, Anim. Feed Sci. Tech. 44: 209-220.

Mohanta, N. G. D. 2005. Improvement of the nutritive value of rice straw through treatment with urea, urease sources and plant leaves. MS Thesis. Bangladesh Agricultural University, Mymensingh, Bangladesh.

Nolte, M. E., Cline, J. H., Dehority, B. A., Loerch, S. C. and Parker, C. F. 1987. Treatment of wheat straw with alkaline solution prepared from wood ashes to improve fibre utilization by ruminants. J. Anim. Sci. 64: 667-669.

NRC. 1984. Nutrient requirements of beef cattle. $6^{\text {th }}$ Rev. Edn. National Academy Press. Washington, DC. USA.

Preston, T. R. and Leng, R. A. 1987. Matching ruminant production system unit with available resources in the tropics and sub-tropics, Prenambul Books, Armidale, Australia. pp. 245.

Puri, J. P. and Gupta, B. N. 2001. Effect of feeding rice straw treated with two levels of urea and moisture on growth and nutrient utilization in crossbred calves. Indian J. Anim. Nutr. 18(1): 54-59.

Ramirez, R. G., Cruz, C. and Gonzalez, C. C. 1992. Effect of treating corn stover with wood ashes and hydroxide on nutrient digestibility by sheep and goats. J. Small Rum. Res. 7: 225-232.

Saadullah, M., Haque, M. and Dolberg, F. 1982. Treated and untreated rice straw for growing cattle. Trop. Anim. Prod. 7: 20-25. 
Schiere, J. B. and Ibrahim, M. N. M. 1989. Feeding of urea ammonia treated rice straw. A compilation of miscellaneous reports produced by the straw utilization project. Kandy, Sri Lanka. pp. 3-4.

Singh, G. P. and Oasting, S. J. 1991. Nutritive value of straw. Proc. International Workshop, National Dairy Research Institute (NDRI), Kamal, Haryana-India, 4-8 February, 1991.

Steel, G. D. and Torrie, J. H. 1980. Principles and Procedures of Statistics. McGrow Hill Book Company Inc., New York.

Suksombat, W. 2004. Comparison of different alkali treatment of bagasse and rice straw. AsianAust. J. Anim. Sci. 17(10): 1430-1433.

Tareque, A. M. M. 1991. Feeds and fodder resources in Bangladesh and patterns of utilization. ADB, Second Livestock Project. TA No. 668 BAN.

Van Soest; Robertson, J. B. and Lewis, B. A. 1991. Methods of dietary fibre, neutral detergent fibre and non starch polysaccharide in relation to animal nutrition. J. Dairy Sci. 74: 3583-3597. 